\title{
Outcome of Diode Laser Assisted Endoscopic DCR
}

\author{
Utpal Kumar Kundu, ${ }^{1}$ MahmudulHasan, ${ }^{2}$ Utpal Kumar Datta, ${ }^{3}$ Md. JoynalAbedin, ${ }^{4}$ Md.OliUllah, ${ }^{5}$ \\ Abdullah Yusuf, ${ }^{6}$ Md. RojibulHaque ${ }^{7}$
}

\section{Abstract}

Background and Objectives: Endoscopic laser dacryocystorhinostomy(DCR) is now a well established, effective approach to relieve nasolacrimal duct obstruction. The aim of DCR surgery is to create a permanent opening between the lacrimal sac \& nasal mucosa in patient of chronic dacryocistitis. There are many methods to perform DCR but our approach was diode laser assisted endoscopic DCR. The Objective is to study the outcomes of diode laser assisted endoscopic DCR.

Material and Methods: This hospital based prospective non-randomized interventional clinical trial included 49 patients with chronic dacryocystitisat National Institute of ENTbetween august 2015 to July 2016. Success and complications were assessed by evaluating the patient at 1 week, 1 month, 3 month, 6 month postoperatively and at least 3 month after removal of silicon tube those who were intubated by nasal endoscopy and sac patency test. Success was defined as absence of epiphora and patency of lacrimal drainage system.

Results: Mean age with SD was $44.96 \pm 15.807$ (Range $13-70$ years). Patients between age group 40 - 60 yrs. was the highest (40.8\%), Female were predominant 35 (71.4\%) than male. Male Female Ratio was 1: 2.5. Septoplasty for DNS in $8(16.33 \%)$ cases, turbinoplastyfor hypertrophied terbinatein 1 case were performed. Complications were injury to middle turbinate, sump syndrome, syneachia and granulation tissue formation. Overall success rate of DCR was seen in $87.76 \%$ cases.

Conclusion: Laserassisted endoscopic DCR surgery eliminate the need of conventional external DCR. It is easy to perform, cosmetically good, high tech and has excellent outcome.

Key Words: Dacryocystitis, Diode Laser, Endoscopy,Dacryocystorhinostomy.

\section{Introduction}

The aim of DCR surgery is to create a permanent opening between the lacrimal sac \& It can be performed through a cutaneous incision, traditionally referred to as external DCR or via a transnasal approach under either direct

1. Dr. Utpal Kumar Kundu, DO, MCPS, MS, Assistant Professor (EYE), Mugda Medical College, Dhaka, Bangladesh. Mobile no.01717225687, email: dr.utpalnio@gmail.com

2. Dr. Mahmudul Hasan; MBBS, MS, Assistant Registrar, National Institute of ENT, Tejgaon, Dhaka. Bangladesh.

3. Dr. Utpal Kumar Datta; MBBS, MS, Assistant Prof.ENT, National Institute of ENT, Tejgaon, Dhaka. Bangladesh.
4. Dr. Md. JoynalAbedin, DLO, MCPSMedical Officer, National Institute of ENT, Tejgaon, Dhaka. Bangladesh.

5. Dr. Md. Oli Ullah, Medical officer, National Institute of ENT, Tejgaon, Dhaka. Bangladesh.

6. Dr. Abdullah Yusuf, Assistant Professor, Microbiology, National Institute of Neuroscience and Hospital, Dhaka.

7. Dr. Md. RojibulHaque MBBS, MS, Prof. of ENT and HNS, National Institute of ENT, Tejgaon, Dhaka. Bangladesh. Mobile No: +8801711676039, email: rojibul@yahoo.com

\section{Corresponding Author}

Dr. Utpal Kumar Kundu DO, MCPS, MS, Assistant Professor (EYE),Mugda Medical College, Dhaka, Bangladesh. Mobile no.01717225687, email: dr.utpalnio@gmail.com 
visualization or endoscopic guidance. In both approaches, the lacrimal sac mucosa is connected to the nasal mucosa above the level of the mechanical obstruction at the nasolacrimal duct. ${ }^{1-6}$

External DCR is performed in a standardized fashion: a skin incision is made, the lacrimal bone is removed, and the sac mucosa is connected to the nasal mucosa over a silicone stent. Endoscopic or endonasal DCR, however, though maintaining the same surgical principles, has been described in numerous variations. , $^{3,6-10}$ Some simply involve removal of the nasal mucosa; the creation of a bony opening at the level of the lacrimal bone using a bone rongeur, ${ }^{11}$ power drill, ${ }^{12}$ or laser ${ }^{7}$; and then stripping the lacrimal sac to create a direct fistula from the sac to the nose. Others perform a more complicated surgery by creating a flap from both nasal mucosa and lacrimal sac bridging the bony opening. ${ }^{13-15}$

The first intranasal DCR was performed by Caldwell in $1893 .{ }^{16}$ Endonasal endoscopic DCR was first performed by Rice in 1988, and popularized by McDough\&Meiring in 1989. ${ }^{17}$ Since the description of endonasal endoscopic DCR, a number of modifications using lasers have also been described as a useful tool in endoscopic DCR. Modifications have been described using the Holmium: YAG, argon, carbon dioxide and KTP laser. $^{16,}$ A transcanalicular approach with the Neodymium: YAG laser has also been described. ${ }^{17}$ Precise cutting, easy removal of tissue by ablation, minimal trauma to adjacent tissues are the some advantages of Laser DCR over conventional method.

Usually in Bangladesh, External DCR is practiced by ophthalmologist. Very few ENT surgeonspractiseedendonasal endoscopic DCR as facilities and training is not available in the country. Diode and CO2 Laser are the recent addition in very few Eye and ENT hospitals of Bangladesh.

Beside other Eye and ENT Laser surgeries, Laser assisted endoscopic DCR surgery using a
Diode laser is regularly performed now-a-days. This article assessed the use of the transcanalicular diode laser for endonasal DCR and the outcomes of this modality.

\section{Material and Methods}

This was a prospective non randomized interventional clinical trial. The objective of the study was to assess the outcomes of diode laser assisted endoscopic DCR. This prospective study was carried out in National Institute of ENT, Tejgaon, Dhaka for the period of one year from $1^{\text {st }}$ august 2015 to $31^{\text {th }}$ july 2016 . Total 49consecutive patients, who had acquired nasolacrimal duct obstruction with or without nasal pathology referred to this hospital for laser assisted endoscopic DCR operation, were included in the study. In this study, $980 \mathrm{~nm}$ diode laser was used in repetitive pulse. Laser setting was $8-10 \mathrm{~W}$, pulse length $90 \mathrm{~ms}$. Laser light was delivered through a $0.35 \mathrm{mmoptic}$ fibre. A silicone tube was passed through the canaliculi and kept in place for 2.5to 3months. In some cases no silicon tube was introduced. Identical topical antibiotics and steroid drops were prescribed in tapering dose for one month in each patient. Success and complications of patients were assessed by evaluating the patient at $7^{\text {th }}$ pod, 15th pod, after 1 month, after 3 month, after 6 month postoperatively and at least 3 month after tube removal by nasal endoscopy and patency of osteotomy by lacrimal system irrigation. Success was defined as absence of epiphora andpatency of osteotomy by lacrimal system irrigation.

\section{Result}

A total of 49eyes of 49 patients were operated.Male were $14(28.6 \%)$ and female were $35(71.4 \%)$. Male to Female ratio was observed with1:2.5.Age range of the patients was13 - 70 yrs. Mean agewith SD was 44.96 \pm 15.807 .24 (48.98\%)were operated on the right eye and $25(51.02 \%)$ on the left eye.Associated correction of nasal diseases (Septoplasty 8 for DNS, turbinoplasty 1 for hypertrophied turbinate) was donein 9 cases. The commonest per operative complication was injury to the middle turbinate (2 cases). The postoperative 
complications were Sump syndrome (1case),synaechia in the nasal cavity (1 case) and granuloma at the ostium (1 case).The overallsuccess rate was observed in $87.76 \%$.

Table -I: Distribution of age $(n=49)$

\begin{tabular}{|c|c|c|c|}
\hline \multicolumn{2}{|c|}{ Age Group } & Frequency & Percentage \\
\hline \multicolumn{2}{|c|}{ Less Than 20 yrs } & 04 & 08.2 \\
\hline \multicolumn{2}{|c|}{20 to $40 \mathrm{yrs}$} & 17 & 34.7 \\
\hline \multicolumn{2}{|c|}{40 to $60 \mathrm{yrs}$} & 20 & 40.8 \\
\hline \multicolumn{2}{|c|}{ More than 60 yrs } & 08 & 16.3 \\
\hline \multicolumn{2}{|l|}{ Total } & 49 & 100.0 \\
\hline \multicolumn{4}{|c|}{$\begin{array}{l}\text { Mean } \pm S D=44.96 \pm 15.807 \text { (Range }-13-70 \\
\text { years) }\end{array}$} \\
\hline \multicolumn{4}{|c|}{ Table - II: Distribution of Sex $(n=49)$} \\
\hline Sex & Freq & Jency & Percentage \\
\hline \multirow{2}{*}{$\begin{array}{l}\text { Male } \\
\text { Female }\end{array}$} & & 14 & 28.6 \\
\hline & & 35 & 71.4 \\
\hline Total & & 49 & 100.0 \\
\hline
\end{tabular}

Male: Female - 1: 2.5

Table - III: Site of operation performed $(n=49)$

\begin{tabular}{|l|c|c|}
\hline $\begin{array}{l}\text { Site of } \\
\text { operation }\end{array}$ & Number & Percentage \\
\hline Right & 24 & 48.92 \\
Left & 25 & 51.02 \\
Total & 49 & $\mathbf{1 0 0}$ \\
\hline
\end{tabular}

Table -IV: Overall Success rate of study subject $(n=49)$

\begin{tabular}{|c|c|c|l|}
\hline $\begin{array}{l}\text { Number } \\
\text { of } \\
\text { Patients }\end{array}$ & Success & Failed & $\begin{array}{l}\text { Success } \\
\text { Rate }\end{array}$ \\
\hline 49 & 43 & 6 & $87.76 \%$ \\
\hline
\end{tabular}

Table-V: Associated Nasal surgery

\begin{tabular}{|l|c|c|}
\hline $\begin{array}{l}\text { Name of } \\
\text { operation }\end{array}$ & $\begin{array}{l}\text { No. of } \\
\text { operation }\end{array}$ & Percentage \\
\hline Septoplasty & 8 & 16.33 \\
\hline Turbinoplasty & 1 & 2.04 \\
\hline
\end{tabular}

Table-VI: Complications of surgery

\begin{tabular}{|l|c|c|}
\hline Complications & $\begin{array}{c}\text { No. of } \\
\text { subjects }\end{array}$ & Percentage \\
\hline $\begin{array}{l}\text { Injury to the } \\
\text { middle turbinate }\end{array}$ & 02 & 4.08 \\
\hline Sump symdrome & 01 & 2.04 \\
\hline Synaechia & 01 & 2.04 \\
\hline Granuloma & 01 & 2.04 \\
\hline
\end{tabular}

\section{Discussion}

The aim of new developments in the field of DCR is to shorten the procedure time, to shorten patient recovery time, to decrease complication rate, to avoid surgical skin and mucosal scars, and to make the procedure possible on an outpatient basis under local anesthesia. ${ }^{18}$

The upper and lower punctum ware dilated with punctum dilator with gradually increasing sized probes to create a good passage. The Laser fiber which is 0.35 in diameter was inserted through the puncta and was maneuvered so that it is in contact with the medial wall of the lacrimal sac. At this point, the aiming beam is switched on. This beam is then visualized through the endoscope in the nasal cavity. It has to be ensured that the aiming beam is at the brightest and is not scattered. Switch off the light source so that beam is better visualized. Scattered beam means the probe is still in the sac or is not touching the lacrimal bone. Light gets diffused as fiber tip distance is increased from bone. Laser is fired only after confirmation in short pulseswith equal gap intervals. One must adequately enlarge the hole by pulling back fiber and engulating it. Osteotomy done in this way should be at least 8 to $10 \mathrm{~mm}$ wide. 
Comparing published success rates of lacrimal surgery is a difficult task because different studies use different criteria. ${ }^{19}$

Guidelines ${ }^{19}$ published by the Royal College of Ophthalmologists suggest that lack of tearing 3 months after surgery is a good indicator of successful surgery. Therefore, this study used these guidelines for patients with at least 3 months' follow-up time postoperatively.

The peak age in the present study was the fourth to fifth decade of life $(40.8 \%)$, whereas it was the fifth to seventh decades of life in the report by Emmerichet $\mathrm{al}^{20}$ from Germany and the fourth to fifth decades of life in the report by Kunavisarut et $\mathrm{al}^{21}$ from Thailand. This difference may reflect the geographic-environmental population structure; however, in most studies, as in this study, epiphora was the most prevalent symptom.

Among the total 49 patients of the present study, female were 35 and male were 14. (Male: Female= 1:2.5). In a study ofBrigitaDrnovšekOlup and Matej Beltram, ${ }^{22}$ they observed 89 female and 33 male out of 122 patients. Regarding sex distribution, the present study was in compatible with the previous study.

Associated nasal pathology was corrected by septoplastyfor DNS in 8 cases and turbinoplastyfor hypertrophied turbinate in 1 case. Per operative complication of the present study was injury to middle turbinate in 2 cases and post operative complications were Sump syndrome ( 1 case), synaechia in the nasal cavity (1 case), granuloma at the ostium (1 case). The patients of this series complaint little or no pain post operatively and were able to leave the hospital mostly on the day of operation.

Among 49 operated patients in the present study, we observed absence of epiphora and a patent nasolacrimal duct by irrigation in 43 out of 49 treated eyes. This yielded a overall success rate of the present study was $87.76 \%$. In a study ofBrigitaDrnovšek-Olup and MatejBeltram ${ }^{22}$ the success rate was $83.3 \%$. In other study byHong $\mathrm{JE}^{1}$, Hatton MP, Leib ML, Fay $\mathrm{AM}^{23}$ the success rate was $87.5 \%$. In a study by Gupta SK, Kumar A, Agarwal S, Pandey P. successful outcome was seen in 85 patients (90.5\%) out of $94{ }^{26}$ The success rate of the present study was in compatible with the previous study.But in many studies the success rate were between 70$80 \%{ }^{24,25}$ The higher success rate in the present study might be due to correction of associated nasal pathology.

Advantages of Laser assisted endoscopic DCR include a relatively shorter operating time, precise cutting and removal of tissue by ablation, minimal trauma to adjacent tissue, short recovery period, minimal morbidity, and low complication rate. The procedure can be performed under local anesthesia and on an outpatient basis. The limitations of endoscopic DCR have been described as follows: small rhinostoma, high recurrence rate, costly equipment, and difficult to master. ${ }^{27}$

EL-DCR is a minimally invasive surgical procedure. It takes advantage of accessing the operating field through anatomic pathways. This contributes greatly to minimizing trauma to surrounding tissue and avoiding unnecessary surgical skin scars. The procedure has a fast learning curve and even easier to learn as compared to classical or TNE-DCR. ${ }^{22}$

In this study, a diode laser with flexible fibre had been used. The flexible diode laser fibre heats only at the tip and does not burn or cause stenosis of canaliculi, and it is effective in vaporizing the lacrimal bone. ${ }^{18}$

To achieve a high rate of success, it is very important to be able to visualize the sac from the fundus to the duct and to remove the whole medial wall or at least the lowermost part, with a laser. Wide openings to the nose allow better results and prevent mucosal closure as well as retention pouches caudal to the rhinostomy. ${ }^{26}$

Additionally, in case of restenosis, laser assisted endoscopic DCR can be easily repeated as there is no scarring in the lacrimal pathway or any anatomical alteration. ${ }^{22}$ 


\section{Conclusion}

Laserassisted endoscopic DCR surgery eliminate the need of conventional external DCR. It is easy to perform, cosmetically good, high tech and has excellent outcome. Surgeons should have appropriate knowledge and experience about endoscopic surgery, use of Laser, surgical anatomy of lacrimal drainage system and nasal cavity for good outcome

\section{References}

1. Dolman PJ. Comparison of external dacryocystorhinostomy with nonlaserendonasaldacryocystorhinostomy.

Ophthalmology 2003;110:78-84.

2. West JM. A window resection of the nasal duct in cases of stenosis. Trans Am OphthalmolSoc 1914;12:654-8.

3. Caldwell GW. Two new operations for obstruction of the nasal duct, with preservation of the canaliculi. Am J Ophthalmol 1893;10:18992.

4. Mosher HP. Re-establishing intranasal drainage of the lacrimal sac. Laryngoscope 1921;31:492-521.

5. Toti A. Nuovometodoconservatore di curaradicaledellesoppurazionicronichedel saccolacrimale (dacriocistorinostomia). ClinModerna (Firenze) 1904;10:385-7.

6. McDonogh $\mathrm{M}$, Meiring $\mathrm{JH}$. Endoscopic transnasaldacrocystorhinostomy. J LaryngolOtol 1989;100:585-7.

7. Massaro BM, Gonnering RS, Harris GJ. Endonasal laser dacryocystorhinostomy. A new approach to nasolacrimal duct obstruction. Arch Ophthalmol 1990;108:1172-6.

8. Moore $\mathrm{WMH}$, Bentley $\mathrm{CR}$, Olver JM. Functional and anatomic results after two types of endoscopic endonasaldacryocystorhinostomy: surgical and holmium laser. Ophthalmology 2002;109:1575-82.

9. Durvasula V, Gatland DJ. Endoscopic dacryocystorhinostomy: long-term results and evolution of surgical technique. J LaryngolOtol 2004;118:628-32.

10. Mirza S, Al-Barmani A, Douglas SA, et al. A retrospective comparison of endonasal KTP laser dacryocystorhinostomy versus external dacryocystorhinostomy.ClinOtolaryngol 2002;27:347-51.

11. Yung MW, Hardman-Lea S. Endoscopic inferior dacryocystorhinostomy. ClinOtolaryngol 1998;23:152-7.

12. Wong RJ, Gliklich RE, Rubin PA, Goodman M. Bilateral nasolacrimal duct obstruction managed with endoscopic techniques. Arch Otolaryngol Head Neck Surg 1998;124:703-6.

13. Tsirbas A, Davis G, Wormald PJ. Mechanical endonasaldacryocystorhinostomy versus external dacryocystorhinostomy.OphthalPlastReconstrSu rg 2004; 20:50-6.

14. Tsirbas A, Wormald PJ. Endonasaldacryocystorhinostomy with mucosal flaps. Am J Ophthalmol 2003;135:76-83.

15. Massegur $\mathrm{H}$, Trias $\mathrm{E}$, Adema JM. Endoscopic dacryocystorhinostomy: modified technique. Otolaryngol Head Neck Surg 2004;130:39-46.

16. Metson R, Woog JJ, Puliafito CA. Endoscopic laser dacryocystorhinostomy. Laryngoscope 1994; 104(3 Pt 1): 269-74

17. McDonogh $\mathrm{M}$, Meiring $\mathrm{JH}$. Endoscopic transnasaldacryocystorhinostomy.

LaryngolOtol 1989; 103(6): 585-7

18. Malhotra $R$, Wright $M$, Olver JM. A consideration of the time taken to do dacryocystorhinostomy (DCR) surgery. Eye 2003; 17: 691-6.

19. Yung MW, Hardman-Lea S. Analysis of the results of surgical endoscopic dacryocystorhinostomy: effect of the level of obstruction. Br J Ophthalmol 2002;86:792-4. 
20. Emmerich $\mathrm{KH}$, Busse $\mathrm{H}$, Mayer-Rusenberg HW. Dacryocystorhinostomiaexterna: technique, indications and results [in German]. Ophthalmologe. 1994;91:395-398.

21. Kunavisarut $S$, Phonglertnapagorn $S$. Dacryocystorhinostomy at Ramathibodi Hospital. J Med Assoc Thai.1990; 73:47-52.

22.

BrigitaDrnovšek-Olup,

MatejBeltram.Transcanalicular diode laserassisted dacrocystorhinostomy: Indian J Ophthalmol. 2010 May-Jun; 58(3): 213-217.

23. Hong JE, Hatton MP, Leib ML, Fay AM.Endocanalicular laser dacryocystorhinostomy analysis of 118 consecutive surgeries.Ophthalmology. 2005 Sep; 112(9):1629-33.
24. Olver J. Colour Atlas of Lacrimal Surgery. Oxford: Butterworth-Heinemann; 2002. pp. 98-9.

25. Mandeville JT, WoogJJ.Obstruction of the lacrimal drainage

system. CurrOpinOphthalmol. 2002; 13:303-9.

26. Gupta SK, Kumar A, Agarwal S, Pandey P. Transcanalicular laser dacryocystorhinostomy using low energy $810 \mathrm{~nm}$ diode laser. Oman J Ophthalmol 2012; 5:171-4

27. Fayet B, Racy E, Assouline M. Complications of standardized endonasaldacrocystorhinostomy with unciformectomy. Ophthalmology, 2004; 111:837-845 